\title{
Critical Discourse Analysis on Teacher Talks in the Classroom Communication
}

\author{
HASANUDDIN \\ Universitas Negeri Gorontalo \\ hasanuddin@ung.ac.id \\ ADRIANSYAH KATILI \\ Universitas Negeri Gorontalo \\ adriansyahkatili@ung.ac.id
}

\begin{abstract}
The research objective was to find out how the teacher arranges her/his teacher talk in accordance with modification to teacher speech quantity of speech, explanation, question, and error correction. This research is designed in a qualitative research approach with an etnography of communication in which the researcher gathered data about verbal communication, relying on direct observation and audio-video recording. The subjects of research were the Indonesian people who used English in communication at classroom setting. In terms of teacher talk, it is found that teachers arranged their teacher talk in acordance with (1) modification to teacher speech when giving understanding, clarifying, and simplifying their speech for developing quality of teaching and learning process, (2) quantity of speech of the teachers was limited in order to give a maximum opportunity to students in the classroom communication, (3) explanation was done to give the students theoretical knowledge, (4) question was delivered to develop indepth content and teaching material, and (5) error correction was conducted to correct students' error in any language usage and language use.
\end{abstract}

Keywords: Critical Discourse, Teacher talk, Communication strategy, turn taking, topic management, learning strategy.

\section{INTRODUCTION}

In language teaching, new movements often begin as reactions to old ones. Communicative language teaching especially in teaching English in Indonesia has moved from structurally competent to communicative competent. Structural competent, students are asked to perform their tasks with a perfectly grammatical correct sentence. Most of students are familiar the structurally competent but communicatively incompetent students. Communicative competent, on the other hand, students are asked to perform their communicative competent for communication. Therefore, communicative competent can be developed for giving to our students to take a part in communication in the classroom.

Moving from structural to communicative way of teaching, the use of English increases participations such students and teacher's interaction in the classroom. First, students are able to understand and give respond to their teacher. Second, the teacher is able to communicate their teaching his students. The interaction and turn-taking occurs when the teacher can create their teaching process. Then students can follow well and understand their teacher's language 
classroom. Finally, communicative teaching happens if there is communication among students and their teacher in the classroom.

In implementing communicative teaching, we can find out different situation with structural way of teaching. We can provide the students with the something else essential for communicative ability. Communicative ability is the students have ability in relating to grammatical competence, sociolinguistic competence, discourse competence, and strategic competence (Huda, 1999). Grammatical competence involves the mastery of language codes both verbal and non verbal. Sociolinguistic competence deals with socio-cultural and discourse rules. Discourse competence is concerned with the mastery of ways to combine grammatical forms and meaning to produce either a spoken and written utterance wholly in various form. Strategic competence consists of the mastery of both verbal and non-verbal communication strategies used by a speaker.

Communicative language teaching starts with developing semantico-grammatical and functions or communicative function categories (Johnson and Morrow, 1981). They said that semantico-grammatical category is the means of listing concepts and uses in our syllabus. The concepts of grammatical structure of a language have to be known a speaker of language; and semantic category has to be understood. While communicative function is the uses to which we put language.

Communication in the classroom is one aspect of teaching and learning process that happens when the teacher and students interact in the classroom. Communication that occurs in the classroom can be found some important issues to be studied. For instance, how do students take and turn in speaking?, What interaction do happen in the classroom? What communication strategies do the students use in the classroom? Those issues can be investigated by using critical discourse and pragmatic analysis.

Communication in the classroom is focused on how teacher arrange his/her talk (teacher talk) that consists of modifications to teacher speech, quantity of speech, explanations, question, and error correction. There has been much research on teacher talk in recent years. This interest reflects the importance of such talk in language teaching. As it is so important for language teachers, issues which have been investigated include the amount and type of teacher talk, speech modifications made by teachers, instructions and explanations, types and number of questions asked and error correction.

Pica and Long in Nunan (1989) investigated the linguistic and conversational performance of experienced and inexperienced teachers. The purpose of the research was to determine whether there were differences in the speech characteristics of experiences and inexperienced teachers in their classroom interactions. Two questions addressed by Pica and Long are as follows: (1) In what way do teachers modify their speech when talking to second language learners in the classroom? (2) Is the ability to modify one's language appropriately part of any teacher's competence, or must it be developed through experience over time?

The researchers found that ESL classroom conversation differ from conversation outside the classroom in a number of ways. There was much less negotiation for meaning in the classroom (this was measured by the number of times teachers adjusted their speech to check that students understood them and they had correctly understood the learners).

Learner language in the context of interaction, we can look at some of the discourse features of classroom interaction which have been investigated in first and second language 
classroom, and which might provide suitable topics for investigation. The framework of this section comes from the analysis of interactions that they came to appreciate the complexities of the rules and regularities underlying interpersonal communication.

Vital for all discourse and communication is who controls the topics (semantic macrostructures) and topic change, as when editors decide what news topics will be covered (Gans, 1979; Van Dijk, 1988a, 1988b), professors what topics will be dealt with in class, or men may control topics and topic change in conversations with women (Palmer, 1989; Fishman, 1983; Leet-Pellegrini, 1980; Lindegren-Lerman, 1983). As with other forms of discourse control, such decisions may be (more or less) negotiable among the participants, and depend very much on context, that is on how participants interpret the communicative situation.

Although most discourse control is contextual or global, even local details of meaning, form or style may be controlled, e.g., the details of an answer in class or court, choice of lexical items or jargon in courtrooms, classrooms or newsrooms (Martin Rojo, 1994). In many situations volume may be controlled and speakers ordered to 'keep their voice down' or to 'keep quiet', women may be 'silenced' in many ways (Houston \& Kramarae, 1991), and and in some cultures one need to 'mumble' as a form of respect (Albert, 1972). The public use of specific words may be banned as subversive in a dictatorship, and discursive challenges to culturally dominant groups (e.g., white, western males) by their multicultural opponents may be ridiculed in the media as 'politically correct' (Williams, 1995). And finally, action and interaction dimensions of discourse may be controlled by prescribing or proscribing specific speech acts, and by selectively distributing or interrupting turns (see also Diamond, 1996).

Across levels, what we may conclude from many critical studies is the prominence of overall strategy of Positive Self-Presentation of the dominant ingroup, and Negative OtherPresentation of the dominated outgroups (Van Dijk, 1993a, 1998b). The polarization of Us and Them that characterizes shared social representations and their underlying ideologies is thus expressed and reproduced at all levels of text and talk, e.g., in contrastive topics, local meanings, metaphor and hyperbole, and the variable formulations in text schemata, syntactic forms, lexicalization, sound structures and images.

Virtually all levels and structures of context, text and talk can in principle be more or less controlled by powerful speakers, and such power may be abused at the expense of other participants. It should however be stressed that talk and text do not always and directly enact or embody the overall power relations between groups: It is always the context that may interfere, reinforce or otherwise transform such relationships. Obviously not all men are always dominant in all conversations (Kotthoff \& Wodak, 1997; Tannen, 1994a), nor all whites or professors, for that matter.

In the process of communication every speaker adjusts the way he speaks according to the situation he is in, the purpose which motivates him, and the relationship between himself and the person he is addressing. This situation of conversation is simply identified within the frame of location, participants, topics, and purposes. An adult IL speaker will find communication problems more complex, because he faces the constraints of language proficiency, communication rules and social norms applied in different speech contexts.

Moreover, Selinker (1972) and Bialystok (1990) set out the strategies in the development of interlanguage. They edintify five processes of interlanguage development: language transfer, overgeneralization of target language rules, transfer of training, srategies of second (L2) learning, and strategies of L2 communication. These five processes jointly bear responsibility 
for the movement of the interlanguage along some hyphotetical continuum towards the norms set out by the target language. The two strategies (pertaining to learning and communication) enjoy equal status with the other processes, and the evaluative criteria in all cases are not theoretical psychological system, but measurable differences in the form of interlanguage as a function of these factors. Thus, Selinker would claim that there is no important distinction between strategies and processes. In interlanguage view, strategies of learning need to be distinguished only from strategies of communication.

\section{FOCUS AND OBJECTIVE}

Communication in the classroom is focused on how teacher arrange his/her talk (teacher talk) that consists of modifications to teacher speech, quantity of speech, explanations, question, and error correction; How does teacher arrange his/her teacher talk in accordance with modification to teacher speech, quantity of speech, explanations, question, and error correction?The objective of this research is to find out how the teacher arranges his/her teacher talk in accordance with modification to teacher speech, quantity of speech, explanations, question, and error correction.

\section{THE SIGNIFICANCE OF STUDY}

There are two significances of the study. Theoretical Significance, this study has a contribution to theory of applied linguistics than focus on how teacher arranges their teacher talk according to modification to teacher speech, quantity of speech, explanations, question, and error correction; and also how the students interact according to turn taking, topic management, learning strategies, and communication strategies. On the other hand, practical significance, teacher can apply his/her teaching activities according to good modification of teacher speech; teacher can arrange quantity of speech and balance opportunity with the students; teacher can manage his/her explanation, question, and error correction. Finally students can select a good interaction with a good turn taking, topic management, learning strategies, and communication strategies.

\section{RESEARCH METHODOLOGY}

This part deals with methodological procedures of this research. It consists of (1) research design, (2) instrument (3) subjects and site of the study, (4) data of the study, (5) data collection, (6) data analysis, and (7) trustworthiness of the study.

\section{RESEARCH DESIGN}

This study is exploratory and descriptive. It attempts to describe communication in the classroom which is focused onhow teacher arrange his/her talk (teacher talk) that consists of modifications to teacher speech, quantity of speech, explanations, question, and error correction.

\section{INSTRUMENT}

The main instrument of the present study is the investigators themselves. They act as instruments and data collectors at the same time. By using a handicam the oral communications between the teacher of English and the students of English themselves are recorded. The field notes, in addition to the recorded data are taken directly in the field. The field notes are written descriptions of what is heard, seen, experienced in the data collection. Theories of critical discourse analysis, communication strategies, pragmatics, sociolinguistics are further used in 
order to sort and interpret the data. The data are sorted and interpreted to develop the research findings.

\section{SUBJECTS AND SITE OF THE STUDY}

The subjects of this research would be the Indonesian people who used English in communication in classroom setting. The sample subjects in this study were the Indonesians who at the time of observation communicate in English with the Indonesian speakers (IS) of English. Indonesian speakers of English were students and teachers that were using English in the classroom for implementing teaching and learning process. The speech situations and the number of Indonesian speakers that were recorded as the sample consisted of 60 subjects for academic contexts and academic setting in teaching Introduction to Literature, ELT Assessment, and English Grammar subjects.

\section{DATA AND DATA COLLECTION}

The data of the study were the oral communication of the teachers and students who at the time of observation communicated in English. The data consist of dialogues and interactive discussion which were represented in utterances. The technique of data collection is observation. Most of the data were audio and video-recorded and the rest were in the form of field notes. The recorded verbal interactions or communicationin the classroom were transcribed, and the transcriptions were used as the data. The field notes, in addition to the recorded data, were taken directly in the field.

\section{DATA ANALYSIS}

Analysis after data collection was done by careful reading, and by examining the data and paying attention to regularities in order to develop coding categories. The coding categories were led by critical discourse analysis relevantly developed from (1) problem statements, and (2) regularities taking place in the data examined. The data analysis is mainly qualitative. The basic unit of analysis is the speaker's utterance as a linguistic unit. The speakers' utterances were analyzed by using critical discourse analysis, pragmatics, and ethnography of communication.

\section{THE TRUSTWORTHINESS OF THE STUDY}

To establish the credibility of the present study, triangulation was applied. Triangulation techniques consist of four types. They are (1) data triangulation, (2) investigator triangulation, (3) theory triangulation, and (4) methodological triangulation (Denzin, 1978:295). In the present study, the four types, namely (1) data, (2) methodological, and (3) theoretical triangulation, and (4) investigator triangulation were employed.

\section{DATA TRIANGULATION}

Data triangulation is a process in which various sources of data are collected. The variety of sources can refer to time, space, and person (Denzin, 1978). In this present study, this triangulation was conducted by including verbal interaction or communication between the teachers and the students in the classroom. 


\section{METHODOLOGICAL TRIANGULATION}

Methodological triangulation is a process in which various methods are used to measure the same unit (Denzin, 1978). This type of triangulation uses either (1) the same method on different occasions, or (2) different methods on the same object of study. In this study, triangulation was done by employing different methods of collecting data, namely (1) observation and field notes, and (2) tape-recording or handycamp.

\section{THEORETICAL TRIANGULATION}

Denzin (1978) classifies the strategies of using theories in triangulating data into three types. First, multiple perspective theories are used to formulate hypotheses, and data are collected in order to assess the power and the utility of the hypotheses. Second, theories which are relevant to the research problems are selected; they are then used to make senses of the problems being investigated. Finally, a theory is used as the base of additional formulation of another theory, which is called "middle-range" theory that only pertains to the data under analysis. These descriptions indicate that the first and the third strategies deal with the finding or building of a new theory.

In the study, the second strategies were used because this study is not meant to derive a new theory, instead it is meant to find out the existing theories of critical discourse and communication strategies that would be applied in inside the classroom setting or academic purposes. The application of this strategy of theory triangulation would result in the forms of discussion of research findings from the point of view of the existing theories.

\section{INVESTIGATOR TRIANGULATION}

This triangulation is done to cross check data from other members of investigators. Data that we have already collected were clarified for further developing supported data that we need in research findings. The research findings that we have already been formulated were discussed more detail. The results of team members discussion were accurately verified to make accurate conclusions.

\section{FINDINGS AND DISCUSSION}

Communication in the classroom is focused on how teacher arrange his/her talk (teacher talk) that consists of modifications to teacher speech, quantity of speech, explanations, question, and error correction. According to the focus of the research, discussion is developed according to the research questions. The research questions are how does teacher arrange his/her teacher talk in accordance with modification to teacher speech, quantity of speech, explanations, question, and error correction? Discussion, moreover, is developed by comparing research finding and relevant research or theories related to the focus of research. The Focus of teacher talk is accordance with modification of teacher speech and quantity, explanation, question, and error correction.

\section{TEACHER TALK IN THE CLASSROOM COMMUNICATION}

The research findings indicate that teachers arranged their teacher talk in accordance with (1) modification to teacher speech that were occurred to give understanding, clearifying, and simplifying their speech for developing quality of teaching and learning process, (2) quantity of speech for terachers was limited in order to give maximal opportunity to students to take a 
part in the classroom communication, (3) explanation was done by the teachers to give students theoretical bases for developing input to students, (4) question was delivered to develop indept content and teaching materials to be given, and (5) error correction was conducted to correct students error in any aspects of language use and language usage in the classroom communication. For further supported data were in the following section.

\section{MODIFICATION TO TEACHER SPEECH AND QUANTITY}

Teacher speech in the classroom communication was done when the teacher gave opportunity to students to discuss in group section. The teacher explained what the main point to be discussed by the group. The group discussion was led by the students themselves. The interactions among the students and other participants happened when they understood the topic of discussion. If the students misunderstood, the teacher took turn and made speech. Therefore, the teachers have the second turn to speech. Beside that the teacher also gave speech when the end of students' discussion.

In accordance with the observation concucted to ELT Assessmens, Introduction to Literature and English Grammar shows that teachers modified their speech when they explained the teaching materials for developing understanding of the students in any context of teaching. They also modified their English for giving additional comments when there were unclear materils that the students uttered.

The ability to modify teacher speech is according the experience and performance of teachers in teaching and learning process. The teacher who taught at at different class setting has a different of modification of his/her speech. Therefore, each classroom context has a different way of speech modification.

In one hand, the teachers of English who taught ELT Assessment, and Introduction to Literature, have a limited opportunity to speech. This is because generally English teachers who were observed, used students' center approach. They used group discussion techniques and each group was asked to present their materials according to the topic to be discussed. While the teacher just gave intoroductory speech to manage a group discussion and modified unsatisfied discussion. Therefore, the students were given opportunity most of the time for taking turn in communication in the classroom and some of the time was used by teachers. On the other hand, in English Grammar the tacher spent most the time to explain the lesson. This is because the teacher gave them a cognitive knowledge about grammatical structure of English.

In perspectrive of critical discourse, modification to teacher speech is done to negotiate meaning and understanding of students about teaching materials. This is supported by Pica and Long research findings. Pica and Long in Nunan (1989) addressed their research questions into (1) in what ways do teachers modify their speech when talking to second-language learners in the classroom? and (2) is the ability to modify one's language appropriately of any teacher's competence, or must be developed through experience over time? They found that ESL classroom conversation differed from conversations out of the class in a number of ways. There was less negotiation for meaning in the classroom. This was measured by the number of times teachers adjusted their speech to check that students had understood them and they had correctly understood the students.

In the context of quantity of speech, teachers gave the students to take a turn most of the time. They led the students to make group discussion and disvcussed their topics and each student gave opportunity to take a turn. But in reality, only a few students used their time to 
speak. It happened because (1) they didn't know well the topic to be discussed, (2) they were difficult to utter their speech because of not self confidence, (3) they had a low language competence to communicate their ideas.

\section{EXPLANATION}

Explanation the teaching materials came to not only from the teacher but also from the students. The teachers gave more oportunity to the students to explain more about the topic to be discussed. This was done because the teacher used discussion group technique to apply thier teaching and learning process. The teacher explained the materials for additional explanation if there is something unclear from students' explanation. Therefore, some sample extracts delivered by the students that were presented in the following.

Sample extract 1 and 2 indicates that it was confusing explanation provided by provided by the students. So, the teacher gave additional explanantion to say that a literature can change human behavior if the students appreciate the literature in a psychological aspect and affective aspect in their behavior. If the students in group discussion and other participants were difficult to explain the concept of related topics the teacher shoud explain to develop the students' cognitive competence.

Sample extract 3) the eight speaker presented a clear and organized idea of opinion, because she delivered it point per point, and also that her idea is still coherent with the theme of the discussion. Then the presenter clarified his explanation and said that the definition of character are group of people to have strong or weak character, personal quality to have the ability, a person particulary unpleasant or strange one that a people have a few can be trusted or related usual quality and place. The students said in their explanation

\footnotetext{
If we learn about that have possitive matter or negative matter of our behavior, generally the drama can make the audience get some knowledge, ans then some knowledge about life or moral value. change human behavior or the kinds of literature that all.

So, I think literature can
}

Therefore, teachers and students developed their explanation by giving some additional reasons and argumentation.

Beside that the partisipant more over explained that the intern analisis is all kind of inter aspect that happen in the prose by Hamingway. The character of Hamingway itself always imitate the truten. So, everytime, he makes a strong, of course about prose. He likes to imitate real life, So does this prose, A clean.well-delighted place.He also imitates the real life. Actually, the intern part of this prose is that hamingway. Compare about two aspects, light needs darkness, in kinds of way. In the real way and conotation meaning. He also says about the real meaning of darkess and light and that's all thank you. I give the authority back to the moderator. Therefore, the presenters gave a clear explanation about the topics to be discussed.

Sample extract 4) as the moderator, he tried to make the presenter and the audience understood about the question before. Then, he gave the alternative explantion the questioner so that the discussion would be better. This discussion was running well under the control of the moderator because he always explains or makes question and answers more clearly. At the same time, the teacher also gave additional explanation about the topic to be discussed by group of discussion. Finally at the end of the section, the teacher explained more detail related to main point of the discussion and summarized the result of the discussion. 
Introduction to Leterature was taught to ask students to be a critical thinking and gave opprtunity to students appreciated a literature. The teacher of Introduction to Literature had to give about what aspects to be analyzed for literature appreciation. For instance, the actors, theme, scenarios, ect. Therefore, the students can develop their literature critics.

\section{QUESTIONS}

Questions came both from the teachers and the students. The teachers asked questions for managing the classroom communication. Questions for managing classroom communication was addressed to the students in order to reinforce students' attention and their understanding teaching materials. The teachers' questions were more didactic function in order to see also learning outcomes.

According to the data presented in sample extracts indicates that the teachers used display questions in their classroom communication. A display question is one to which questioner knows the answer that functioned to assess the students' performance. Beside that the teachers also used a referential question that is one to which the person asking the question does not know the answer. The referential question was used for didactic function and clarification of teaching materials and instruction. The following sample extracts were displayed to give evidences according to questions in the classroom communication.

Sample extract 5) some of these questioners ( like eight speaker and ninth speaker) are those who could be included into represent questions. They askedthe questions that they did not know the answer. So, they really hoped that the presenter answered their questions clearly, while the questioner ( seventh speaker) was included into display question because she did not ask to explain the problem ,but she just asked to give the reason of the presenter to choose character on the other character method. For instace, asking about character on the character, what is the interest point of this story? This is the sample of critical thinking and cognitive developmental process that happened to students.

For critical discourse perspective, questions were addressed to groups of discussion that were difficult to be answered should be taken and explained by teachers. If the teachers answered and explained questions from the students, the students would not miss concept about the problems that were discussed. Therefore, questions for the instructional contexts had pedagogical function to make teaching and learning process running well.

Sample extract 7) questioner asked a question to clarify into display question because he just want the presenter to show him the relation of theme of the story. It means that, he hasalready known that there is relation between them. For instace, So could you make compare about the message from detail of this story? Why does the story interest so it will be interest for us. These questions asked to presenters, but they did not answer well according to the questions addressed to them. They needed to answer the questions with comparative way of thinking and reasoning.

Sample extract 12) the first questioner asked a simple question. She/he asked about the base language for the United States and development of standard assessment, like what is the bases languages for united states and development standard of asessment itself? This question could be answered with the presenter according to his/her basic knowledge of assessment itself and it could be classified into referential quesion. The second questioner also required the presenter's oppinion about curriculum, she/he wished to know the presenters' idea or oppinon about curriculum itself. Her second question is that how does the material to be more intreseted 
as according to her basic knowledge that sometomes teacher ignored it and it is a display question. Then, the next questioner asking about standart assessment and it was classified into display question because she/he has already known the answer.

Long and Sato in Nunan (1989:29) have compared the types of questions asked by teachers in class with the types of questions used by native speakers when communicating with secondlanguage speakers in non classroom contexts. Outside the classroom, virtually all the questions addressed to learners were referential, while in class, the opposite was the case (display questions). In another study, Brock in Nunan (1989:29) investigated the effects of referential questions on ESL classroom discourse. He concluded that referential questions may increase the amount of speaking learners do in the classroom. It is also relevant to this research that questions were pedagogiacl function in a language instruction.

\section{ERROR CORRECTION}

The research findings indicate that the teacher gave a correction related to the students' misunderstanding about teaching materials. He explained about authentic assessment according to real performance of the students in the classroom. For instance, in English, the stuudents used English in real communication and the teacher assessed them. The following sample were presented.

Sample extract 15)

Diki : we still reminded by Samsudin is this kind of structuralism analysis or something else, that's why Syarif try to explain about this because he still reminded by the explanation coming from samsudin , that's why try to explain that he still real the story about the next explanation, what about you, do you still satisfy or you still . . . no . . I need to explain that we don't have presents of this group. That's why unfortunately I will not open for the second session, it will be running, not full of attention or satisfaction about the explanation for answer the question that's why we just close, conclusion yes. . . because I'm still about to decide the conclusion itself maybe it would be appropriate to the group it self. And it could be answered by. . . . . the group will be handled by Pemrianty Pade, just for the conclusion

Pemrianty : (she is readning the paper) ok, thanks

Diki : thank you very much Pemry for you conclution, ass. Wr. Wb

Teacher: You have to set up what are the main point to be discussed. Every tittle of discussion should be summarized and finally you make conclusion. (EQ/2)

Sample extract 15) The teacher give a correction to the student who misled about his conclusion. Therefore, the teacher gave a correction according to the way how to summarize and conclude the discussion.

Extract 16)

Questioner. Okey, I get your point. But when you answer my question always changed by time. Jadi penerapan bases yang dimaksud?

Presenter. Aa...sebenarnya standard bases assesmen titu sendiri dalam penerapannya. Dia....agak bingung kita. Misalkan contoh di SMA.

Audience. ( give the answer). Actually standard bases assesment we must have a target. For example goverment determine 4 in national examination, but so the standard is scoring, not other. Can the students improve their quality or not. I mean the system. In UN I never hear about speaking test.

Teacher: Authentic assessment is the assessment that happen in the classroom. The teacher authomatically assess the authentic performance of the students. Authentic is really belongs to the students performance in subject matters. $(\mathrm{II} / \mathrm{EQ} / 2)$ 
The teacher gave a correction related to the students' misunderstanding about authentic assessment. He explained about authentic assessment according to real performance of the students in the classroom. For instance, in English, the stuudents used English in real communication and the teacher assessed them.

\section{CONCLUSION AND SUGGESTIONS}

\section{CONCLUSION}

Teachers arranged their teacher talk in accordance with (1) modification to teacher speech that were occurred to give understanding, clearifying, and simplifying their speech for developing quality of teaching and learning process, (2) quantity of speech for teachers was limited in order to give maximal opportunity to students to take a part in the classroom communication, (3) explanation was done by the teachers to give students theoretical bases for developing input to students, (4) question was delivered to develop in dept content and teaching materials to be given, and (5) error correction was conducted to correct students error in any aspects of language use and language usage in the classroom communication. Five of them were concluded as follows:

1. Teacher speech in the classroom communication was done when the teacher gave opportunity to students to discuss in group section. The teacher explained what the main point to be discussed by the group. The group discussion was led by the students themselves. The interactions among the students and other participants happened when they understood the topic of discussion. If the students misunderstood, the teacher took turn and made speech. Therefore, the teachers have the second turn to speech. Beside that the teacher also gave speech when the end of students' discussion.

2. In the context of quantity of speech, teachers gave the students to take a turn most of the time. They led the students to make group discussion and discussed their topics and each student gave opportunity to take a turn. But in reality, only a few students used their time to speak. It happened because (1) they didn't know well the topic to be discussed, (2) they were difficult to utter their speech because of not self confidence, (3) they had a low language competence to communicate their ideas.

3. Explanation the teaching materials came to not only from the teacher but also from the students. The teachers gave more oportunity to the students to explain more about the topic to be discussed. This was done because the teacher used discussion group technique to apply thier teaching and learning process. The teacher explained the materials for additional explanation if there is something unclear from students' explanation. Therefore, some sample extracts delivered by the students that were presented in the following.

4. Questions came both from the teachers and the students. The teachers asked questions for managing the classroom communication. Questions for managing classroom communication was addressed to the students in order to reinforce students' attention and their understanding teaching materials. The teachers' questions were more didactic function in order to see also learning outcomes

5. The teacher gave a correction related to the students' misunderstanding about authentic assessment. He explained about authentic assessment according to real performance of the students in the classroom. For instance, in English, the stuudents used English in real communication and the teacher assessed them. 


\section{SUGGESTIONS}

1. In the contexts of classroom communication, teachers of English were suggested to develop their ability to modify their communication in the classroom in order to develop the quality of teaching and learning process. The teachers were hoped to give students more opportunity to take a turn in the classroom communication. They also were suggested to explain more clearly the teaching materials and to correct students error early in the process of teaching.

2. For further research, the present study still accommodates a room for improvement. Hence, it is suggested to conduct more related studies to confirm the results of this study, and to get better understanding on teachers talk and students talk or students' interaction in a classroom communication. Therefore, it is suggested to continue this study to examine a comparative study of communication problems and strategies used by IL speakers in academic and social contexts. For future research it is also suggested in other areas: (1) variability in IL communication strategies, (2) non language problems and communication strategies used by Indonesian speakers of English, (3) pragmatic problems and strategies used by IL speakers of English, and (4) learning strategies in productive skills and receptive skills.

\section{REFERENCES}

Agger, B. (1991). A critical theory of public life. Knowledge, discourse, and politics in an age of decline. London: Falmer Press.

Albert, E. M. (1972). Culture patterning of speech behavior in Burundi. In J. J. Gumperz \& D. Hymes (Eds.), Directions in sociolinguistics: The ethnography of communication. (pp. 72-105). New York: Holt, Rinehart and Winston.

Bialystok, E. (1990). Strategies of Target Language Learner Communication, in C. Faerch and G. Kasper (Eds.). Strategies in Interlanguage Communication. New York: Longman.

Caldas-Coulthard, C. R., \& Coulthard, M. (Eds.). (1996). Texts and Practices: Readings in Critical Discourse Analysis. London, England: Routledge.

Calhoun, C. (1995). Critical social theory. Oxford: Blackwell.

Denzin, N.K. (1978). The research Act: A Theoretical Introduction to Sociological Methods (Second Edition). New York: McGraw-Hill Book Company

Diamond, J. (1996). Status and power in verbal interaction. A study of discourse in a close-knit social network. Amsterdam: Benjamins.

Hardt, H. (1992). Critical communication studies. Communication, history, and theory in America. London: Routledge.

Huda, Nuril. (1999). Language Learning and Teaching. Malang: IKIP Malang Press.

Houston, M., \& Kramarae, C. (Eds.). (1991). Women speaking from silence. Discourse \& Society, 2(4), special issue.

Johnson-Laird, P. N. (1983). Mental models. Cambridge: Cambridge University Press.

Klapper, J. T. (1960). The effects of mass communication. New York: Free Press.

Kotthoff, H., \& Wodak, R. (Eds.). (1997). Communicating Gender in Context. Amsterdam: Benjamins.

Liebes, T., \& Katz, E. (1990). The export of meaning: Cross-cultural readings of 'Dallas'. New York: Oxford University Press.

Lindegren-Lerman, C. (1983). Dominant discourse: The institutional voice and the control of topic. In: H. Davis, \& P. Walton, (Eds.) Lannguage, image, media. Oxford: Blackwell, 75-103.

Martin Rojo, L. (1994). Jargon of delinquents and the study of conversational dynamics. Journal of Pragmatics, 21(3), 243-289.

Martin Rojo, L. (1995). Division and rejection: from the personification of the Gulf conflict to the demonisation of Saddam Hussein. Discourse \& Society, 6(1), 49-79.

Nunan, D. (1989). Understanding Language Classroom. Cambridge: Prentice Hall. 
Palmer, M. T. (1989). Controlling Conversations: Turns, Topics and Interpersonal Control. Communication Monographs, 56(1), 1-18.

Selinker, L. 1972. Interlanguage: International Review of Applied Linguistics X: 209 - 30.

Steiner, E. (1985). Towards a critical linguistics. In P. Chilton (Ed.), Language and the nuclear arms debate: Nukespeak Today. (pp. 213-230). London: Pinter.

Tannen, D. (1994). Gender and discourse. New York: Oxford University Press.

Tannen, D. (1994). Talking from 9 to 5. How women's and men's conversational styles affect who gets heard, who gets credit, and what gets done at work. New York: Morrow.

Thomas, J. (1993). Doing critical ethnography. Newbury Park: Sage.

Van Dijk, T. A. (1988a). How 'They' hit the headlines. Ethnic minorities in the press. In G. Smitherman-Donaldson \& T. A. van Dijk (Eds.), Discourse and Discrimination. (pp. 221-262). Detroit, MI: Wayne State University Press.

Van Dijk, T. A. (1988b). News as discourse. Hillsdale, NJ: Lawrence Erlbaum Associates, Inc.

Van Dijk, T. A., \& Kintsch, W. (1983). Strategies of discourse comprehension. New York: Academic Press.

Williams, J. (Ed.). (1995). PC Wars. Politics and theory in the academy. New York: Routledge. 